\title{
MOLECULAR PATHOPHYSIOLOGY OF THROMBOTIC STATES AND THEIR IMPACT TO LABORATORY DIAGNOSTICS
}

\author{
Ludek Slavik $^{\mathrm{a} *}$, Vera Krcova ${ }^{\mathrm{a}}$, Antonin Hlusi ${ }^{\mathrm{a}}$, Jana Prochazkova ${ }^{\mathrm{a}}$, Martin Prochazka ${ }^{\mathrm{b}}$, \\ Jana Ulehlova ${ }^{\mathrm{a}}$, Karel Indrak ${ }^{\mathrm{a}}$
}

\author{
a Department of Hemato-oncology, University Hospital, Olomouc, Czech Republic \\ ${ }^{b}$ Department of Obstetrics and gynecology, University Hospital, Olomouc, Czech Republic \\ e-mail: ludek.slavik@fnol.cz
}

Received: April 24, 2008; Accepted (with revision): December 10, 2008

Key words: Thrombophilia/Genetic causes of thrombophilia/FV Leiden

Background: Molecular genetic methods were implemented in the detection of thrombophilic disorders in the 1990's with the discovery of coagulation inhibitors antithrombin III (AT III), protein C (PC) and S (PS). The discovery of the molecular cause of activated protein C (APC) resistance by Bertina in 1994 greatly expanded their utilization.

Methods and Results: Currently, a broad group of molecular genetic markers with a clearly demonstrated risk of thrombophilia are used - mutation of FV Leiden 506R/Q, mutation of prothrombin (F II) 20210G/A, mutation of methylenetetrahydrofolate reductase (MTHFR) 677C/T in homozygous form, mutation of plasminogen activator inhibitor (PAI-1) 4G/5G, mutations of single coagulation inhibitors as well as a number of polymorphisms with controversial thrombophilic risk such as F XIII Val34Leu, platelet glycoproteins, endothelial protein C receptor and thrombomodulin.

Another area utilizing molecular genetic methods is research of the pathophysiology of individual coagulation processes. To date, the greatest advances in regard to APC resistance have been achieved here. Although the molecular cause of APC resistance was clearly demonstrated in the 1990's, its clinical variability has not yet been fully explained. The same is true for the second most widespread mutation, prothrombin gene mutation, where only the latest research has hinted at a possible mechanism of expression of the genetic changes in the actual coagulation process.

Conclusions: The future of molecular genetic methods is in achieving a complex understanding of the pathophysiology of thrombophilia and not only in its utilization as a method for detecting many polymorphisms with a very low risk of thrombosis.

\section{INTRODUCTION}

Molecular genetic methods provide explanations of the genetic causes of, in this case, thrombophilic disorders. Since the very beginning of the diagnosis of thrombophilic disorders, which arose from the study of families with a high frequency of thrombophilic complications, it was apparent that in a number of cases, the disorder was due to dominantly inherited conditions. Already the discovery of the first families presenting a defect in AT III led to the description of the genetic causes of this defect. As such, over 150 causes of AT III mutation were described.

Molecular genetic methods were implemented into the screening examinations for thrombophilic disorders in the 1990's along with the first discoveries of coagulation inhibitors (AT III, protein C and protein S). The discovery of the molecular cause of APC resistance by Bertina in 1994 greatly expanded their utilization.

Despite the expansion of these methods, the following years brought forth discoveries of defects on a molecular basis, which posed decreasing risks of thrombosis, as can be seen in Fig. 1. However, until the end of the last century, it was understood that only the discoveries of all genetic causes of thrombophilia might lead to the overall elucidation of the genetic risk of thrombophilia.

Currently, it is apparent that there is a deflection from this idea and attention is focused rather on the elucidation of the complex pathophysiology of coagulation at the molecular level.

\section{F V Leiden}

Among the Caucasian population, factor $\mathrm{V}$ Leiden (factor V 1691G-A) is the most common genetic defect causing thrombosis ${ }^{2-7}$. Factor $\mathrm{V}$ mutation was first described by Bertina et al in 1994 at the university of Leiden ${ }^{8}$, based on the discovery of resistance to activated protein C (APC), which was first described in 1993 (ref. ${ }^{9}$ ). The frequency of this mutation in the Caucasian population ranges between 2 and $15 \%$ (ref. $^{2}$ ). The heterozygous form of factor $\mathrm{V}$ Leiden increases the risk of thrombosis 3-8x (ref. ${ }^{2,10,11}$ ), while the homozygous form presents a risk which may be up to 80 times greater $^{12}$.

Factor V Leiden is present in $20 \%$ of patients with venous thrombosis 3,10 and in over half of probands in selected families with thrombophilia. This means that it represents the most common genetic abnormality in patients with thrombosis. 


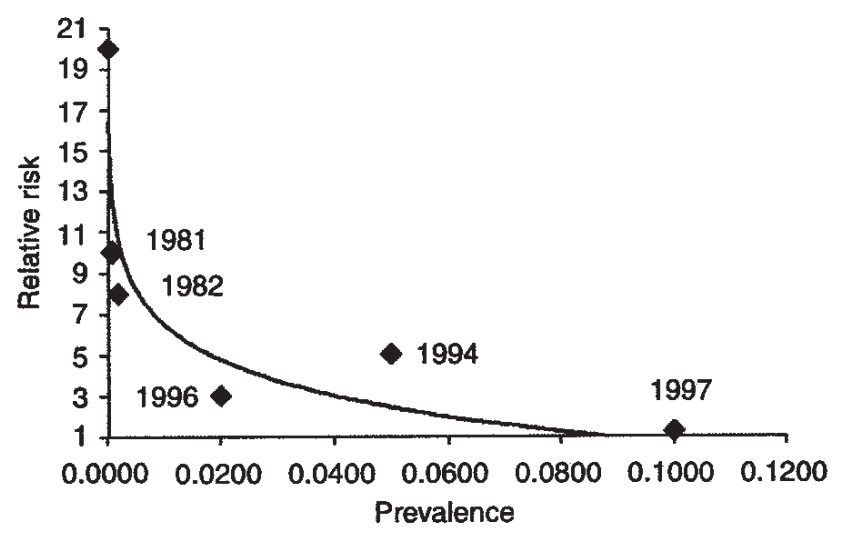

Fig. 1. Prevalence and risk of individual thrombophilic disorders with a time line representing their discovery $^{58}$.

\section{Prothrombin 20210A}

Mutations in the 3'- untranslated region of the prothrombin gene in the position 20210 G-A are associated with an increased level of prothrombin and as such present an increased risk of developing thrombosis ${ }^{13}$. This mutation was described with a high prevalence (18\%) in families with thrombosis and in $6.2 \%$ of patients with first thrombosis ${ }^{13}$.

The mechanism of action of the mutation at the 20210 G-A position of the prothrombin gene is explained to cause an increase in the level of prothrombin, which leads to an increased risk of thrombosis ${ }^{13}$. The prevalence of mutation in the Caucasian population is around $2 \%$ with many geographical variations, such as a higher prevalence of mutation in southern than northern Europe ${ }^{14}$. This causes significant differences between works citing the prevalence of this mutation in the population and the relative risk of the mutation to cause thrombosis. For example, in northern Europe, the prevalence is $2 \%$ (similarly to the Czech population ${ }^{15}$ ) with a relative risk of around 2, while in the Catelonian region of Spain the prevalence is $6.5 \%\left(\right.$ ref. $\left.^{16}\right)$ and the relative risk 2, which represents over $6 \%$ of all thrombosis cases.

\section{Hyperhomocysteinemia}

Slightly increased levels of homocysteine are associated with an increased risk of thrombosis ${ }^{17-19}$. Two studies performed on an undivided group of patients showed that a level of $18.5 \mu \mathrm{mol} / 1$ in $5 \%$ (10\% respectively) of individuals leads to a two-fold increase in the risk of thrombo$\operatorname{sis}^{18-20}$. This means that hyperhomocysteinemia represents $5-10 \%$ of all thrombotic episodes.

Hyperhomocysteinemia may develop due to genetic or acquired dispositions ${ }^{18-21}$. Acquired dispositions primarily include low vitamin intake (B6, B12, folic acid), which leads to an increase in homocysteine level ${ }^{22-23}$. Genetic factors include the very rare cystathione $\beta$-synthetase deficit, whose homozygous form represents classical hyperhomocysteinemia with very high levels ${ }^{24}$, and on the other hand the very common variant of the methyltetrahydrofolate reductase (MTHFR) gene, which leads to the thermolabile enzyme variant with a slightly increased homocysteine lev$\mathrm{el}^{25-27}$. Currently, direct association between the MTHFR 677TT variant, increased homocysteine level and risk of developing thrombosis is not distinctly established ${ }^{28}$.

\section{Antithrombin III}

Egeberg first described familial antithrombin III deficiency in 1965 (ref. ${ }^{29-31}$ ). This first work already pointed out that antithrombin III deficiency is a significantly more serious risk factor for developing thrombosis than protein $\mathrm{C}$ and $\mathrm{S}$ deficiency, and that the majority of patients show clinical manifestation before the age of $25\left(\right.$ ref. $\left.^{30,32}\right)$. This does not pertain to changes of the heparin binding site, which occurs frequently, however does not present a risk in the heterozygous form ${ }^{32}$.

Based on extensive studies, the thrombotic risk for patients with antithrombin III deficiency was determined to be increased five-fold, based on the $1.1 \%$ incidence of the deficiency in patients with venous thrombosis compared to $0.2 \%$ incidence in the control group ${ }^{33}$. Other studies present the incidence of antithrombin III deficiency to be between 1-0.5\% $\left(\right.$ ref. $\left.^{29}\right)$. Among 4000 healthy subjects, the antithrombin III deficit was found in $0.02 \%\left(\right.$ ref. $\left.^{34}\right)$. This data shows that the antithrombin III deficiency is very rare, however, it is a very significant risk factor for developing thrombosis, which is apparent when comparing the prevalence of this defect in patients with venous thrombosis and healthy subjects ( $1 \%$ versus $0.02 \%$ ), which shows that there is a 50 times greater risk in patients with antithrombin III deficiency. Despite this high risk, antithrombin III deficiency represents only $1 \%$ of all thrombotic conditions.

In terms of etiology, antithrombin III deficits may be classified into two groups: inherited and acquired. Inherited deficiency are characterized by a decreased level of antithrombin III antigen, decreased antithrombin III activity, or a combination of these two parameters. These deficits are caused by an inherited defect in the synthesis of antithrombin III or in the synthesis of mutant antithrombin molecules. The disorders are autosomal dominantly inherited.

Inherited antithrombin III deficits are divided into two basic types. Type I, quantitative insufficiency of antithrombin III is characterized by a parallel decrease in activity and antithrombin III antigen. The defect therefore causes a decrease in the rate of antithrombin III synthesis. This defect represents $80-90 \%$ of all antithrombin III defects, where the levels of antithrombin III are decreased to $50-70 \%$ of normal values. Type II, functional defect of antithrombin III, is characterised by a disbalance between antigen concentration and antithrombin III functional activity. The antigen level is therefore normal, but the molecules have a functional defect. Such types of antithrombin include antithrombin with a decreased affinity to heparin (AT III "Budapest", AT III "Milano", AT III "Tokyo"), as well as types with a decreased capability to inactivate serine proteases (AT III "Northwick Park", AT III "Glasgow") and also types with a defective capacity to bind to heparin (AT III "Tours", AT III "Rouen"). Type III 
is characterised by the synthesis of abnormal molecules of antithrombin III, where the level is decreased below physiological values (AT III "Johannesburg", AT III "Budapest 2", AT III "Utah").

Presently, about one hundred mutant types of antithrombin III molecules have been described ${ }^{35,36}$. Introducing a more precise classification of antithrombin III deficiency is complicated by the very low frequency of this disorder.

Acquired deficiency may be present under physiological conditions (for example in newborns, in the late stages of pregnancy) as well as in a number of pathological conditions and present a serious problem. Causes of this deficiency may be decreased synthesis of antithrombin III (in liver cirrhosis, patients treated with asparaginase), increased losses of AT III (gastrointestinal diseases, nephrotic syndrome) as well as increased AT III consumption (disseminated intravascular coagulation after traumas, sepsis, burns, sunstroke and postoperative conditions).

\section{Protein C}

In 1981, the first works regarding increased risk of developing thrombosis in patients with heterozygous deficit of protein $\mathrm{C}$ were presented ${ }^{37,38}$. No difference between patients with various types of deficiency (I or II) and basic mutation were noted. These studies showed that a large majority of patients already has clinical manifestations of the disease at a young age ${ }^{39}$. In addition, it is interesting to note that in some patients, APC resistance was also present as an additional factor increasing the risk of thrombosis ${ }^{40}$.

The prevalence of protein $\mathrm{C}$ deficiency in patients with thrombosis was analyzed by three large studies ${ }^{41-43}$. In all studies, the prevalence of protein $\mathrm{C}$ deficiency was established to be $3 \%$. When compared with the control group, the relative thrombotic risk for protein $\mathrm{C}$ deficit was established to be 6.5 (ref. $^{43}$ ). The $0.2 \%$ prevalence in the healthy population was established based on extensive studies ${ }^{37}$. However, this prevalence in the population combined with the high risk of thrombogenicity results in a 1-2\% contribution of protein $\mathrm{C}$ deficiency on all thrombophilic conditions.

The gene causing protein $\mathrm{C}$ deficiency is autosomal dominantly inherited. Superficial thrombophlebitis and juvenile venous thrombosis types of thromboembolic disease are clinical manifestations of the defect.

In terms of differentiation, two types of protein $\mathrm{C}$ deficiency are described: quantitative (decrease in protein $\mathrm{C}$ antigen) and functional. Functional deficiency of protein $\mathrm{C}$ may be caused by a number of mutations. To date, over 160 different mutations have been described ${ }^{45}$. Heterozygous protein $\mathrm{C}$ defects are associated with a seven-fold increase in the risk of thrombosis.

\section{Protein S}

Protein $\mathrm{S}$ is an important anticoagulation protein, which acts as a non-enzymatic co-factor of APC during inactivation of factor Va and VIIIa. Laboratory screening of protein $\mathrm{S}$ deficiency is complicated by the fact that protein $\mathrm{S}$ circulates in bloodstream in two forms ${ }^{46}$. Forty percent of total protein $\mathrm{S}$ is represented by free protein $\mathrm{S}$, which acts as APC co-factor.

Deficits of protein $\mathrm{S}$ may be divided into three basic forms. Type I is characterised by a decrease in total protein $\mathrm{S}$ most often due to decreased synthesis, type II is characterised by decreased protein $\mathrm{S}$ activity and type III by a decreased level of free protein $\mathrm{S}$ and normal activity of total protein $\mathrm{S}$.

Most deficits are type I or a combination of types I and III. Presently very few cases of type II protein S defi-

A
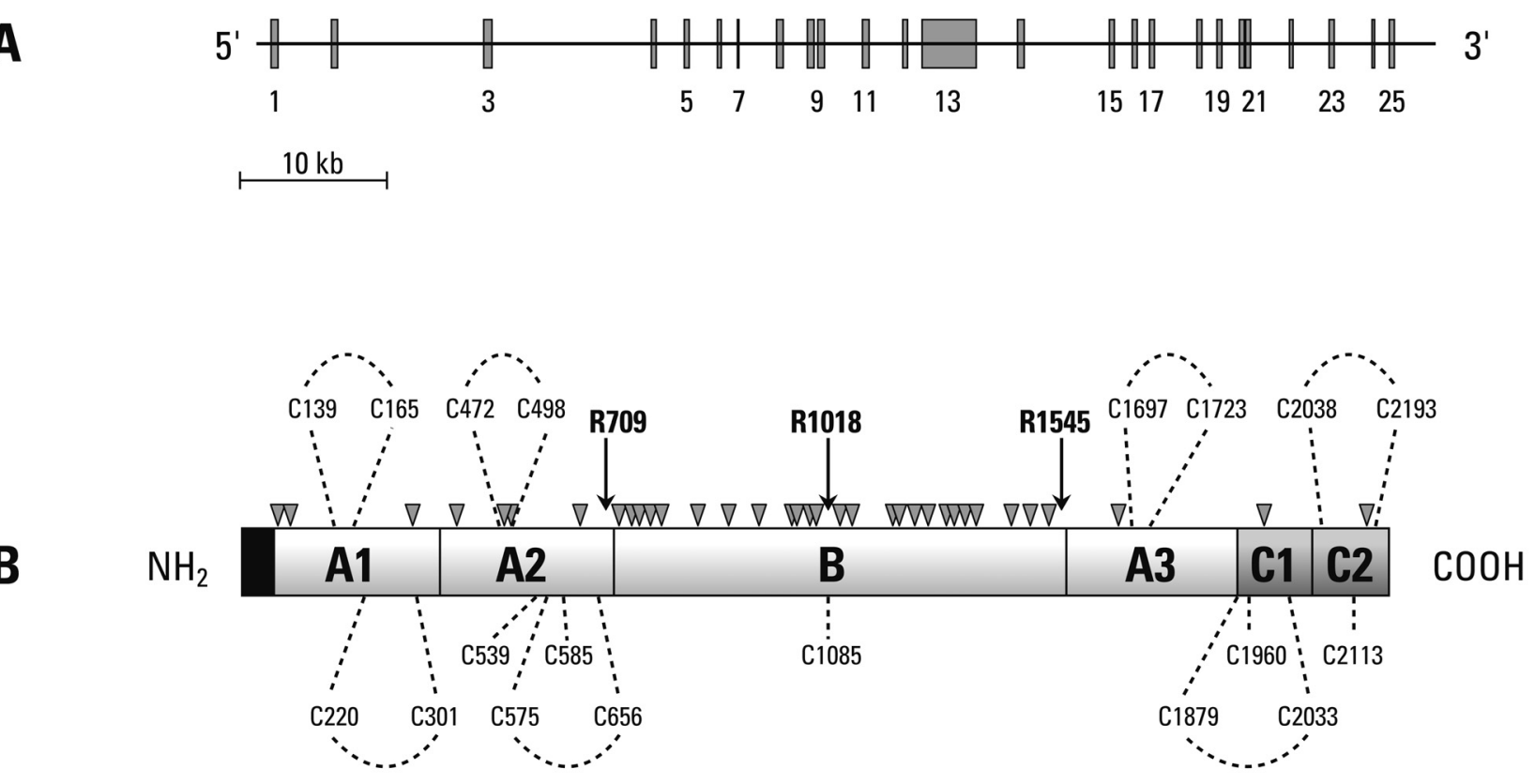

Fig. 2. Schematic representation of the structure of $\mathrm{FV}^{59}$. 


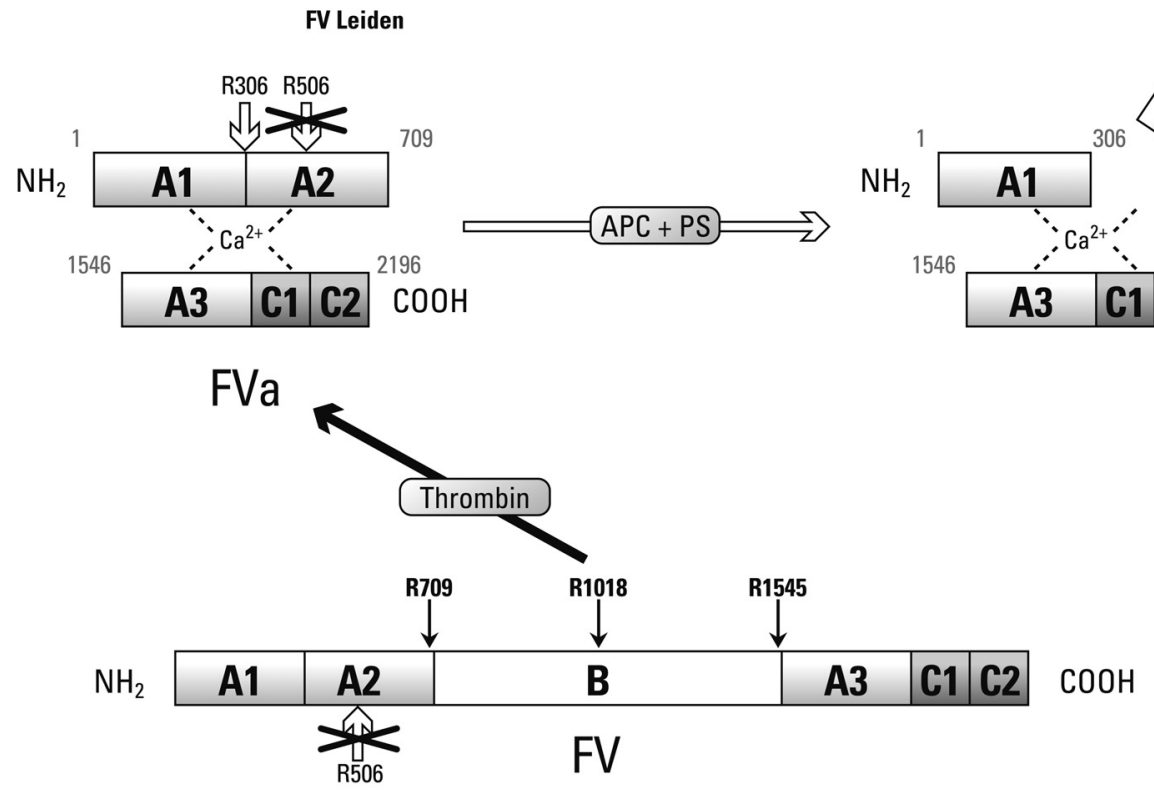

Fig. 3. Procoagulation structure of $\mathrm{FV}^{59}$

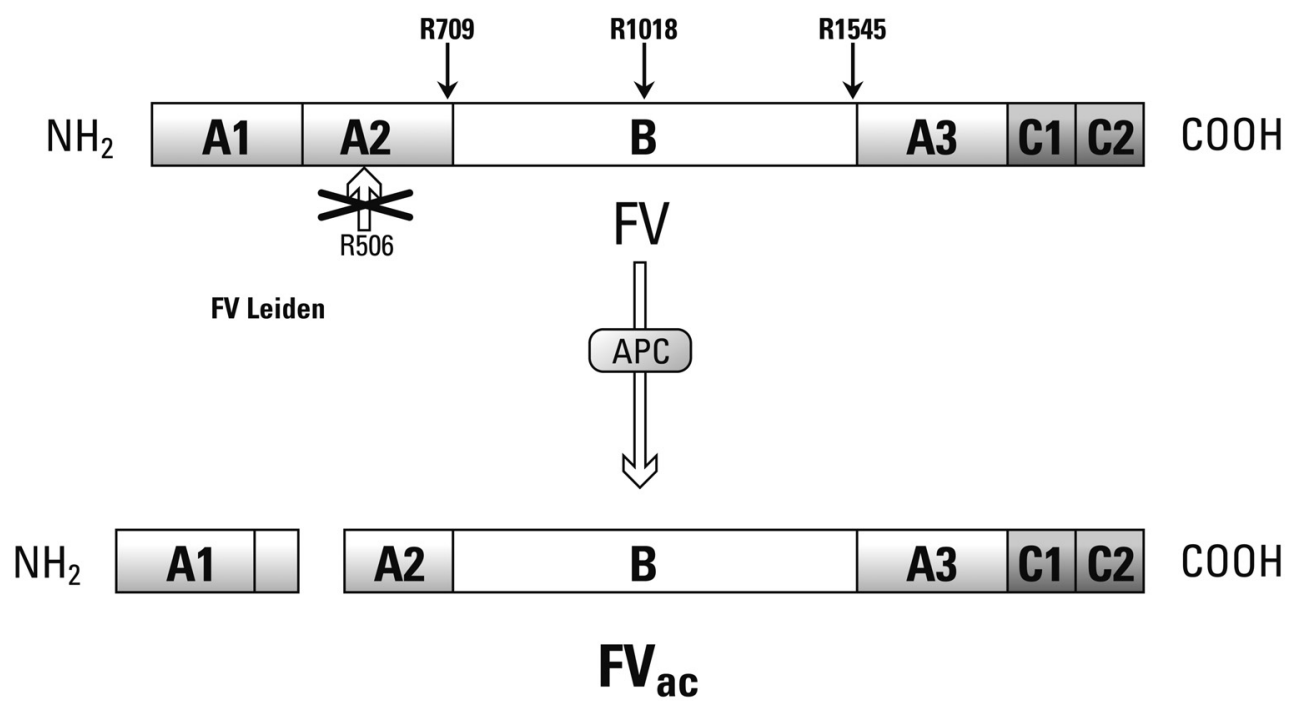

Fig. 4. Anticoagulation structure of $\mathrm{FV}^{59}$.

ciency have been described. The prevalence of protein $\mathrm{S}$ deficiency represents $1-2 \%$ of patients with deep venous thrombosis and $6 \%$ of families with thrombophilia. From a genetic viewpoint, 70 different mutations in the gene for protein $\mathrm{S}$ have been described to date.

\section{Pathophysiology of action FV Leiden mutation}

In terms of pathophysiology of coagulation reactions, FV plays a key role in both procoagulation and anticoagulation cascade processes. In the activated form, it acts as a co-factor of FXa in the prothrombinase complex and as such catalyses the conversion of prothrombin to thrombin. In the inactive form FV acts as APC co-factor in the regulatory activity of FV, IIIa. In inherited and acquired defects, this double role allows FV to influence the manifestation of these disorders into hemorrhagic or thrombotic forms ${ }^{47,48}$. To determine this manifestation, it is necessary to recognize precisely the procoagulation and anticoagulation forms of $\mathrm{FV}$.

The gene encoding human factor $\mathrm{V}$ is composed of approximately $80 \mathrm{~kb}$ and is localized on the long arm of chromosome I. As can be seen in figure 1, the gene comprises 25 exons and 24 introns ${ }^{47}$, which transcribe into $6.8 \mathrm{kB}$ of mRNA, which encodes a chain of 2224 aminoacid residues with 28 signal peptide aminoacids. This peptide is then removed during the translocation into the endoplasmic reticulum.

Molecules of FV created in such manner are present in plasma as a single chain glycoprotein in a concentration of $21 \mathrm{nM}$ (ref. $\left.{ }^{49}\right)(20-25 \%$ of FV continues to be 


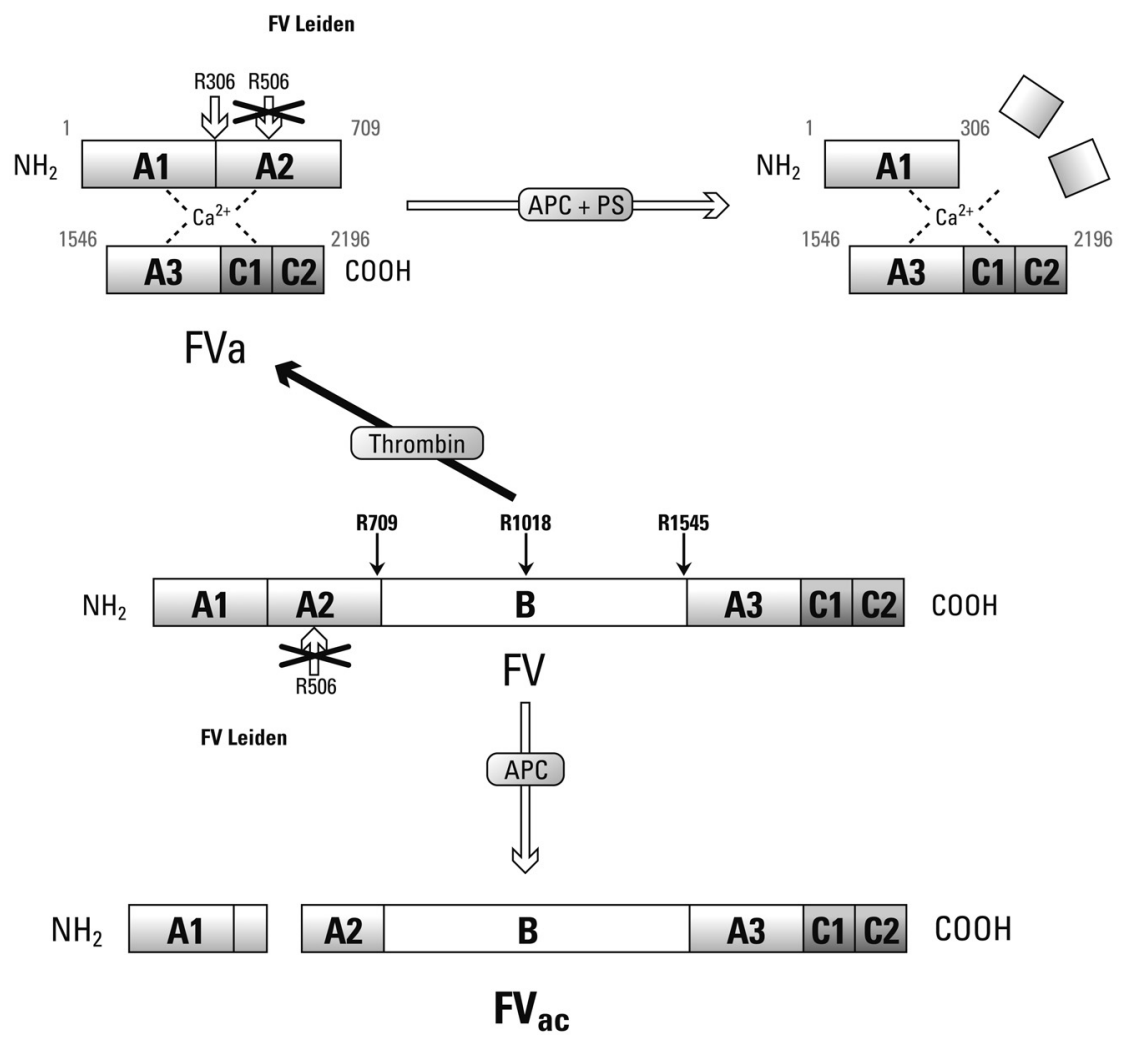

Fig. 5. A schematic illustration of the activation of $\mathrm{FV}$ to procoagulation and anticoagulation forms $\mathrm{s}^{59}$.

stored in $\alpha$ granules of thrombocytes $\left.{ }^{50}\right)$. FV is composed of A1-A2-B-A3-C1-C2 domains with an identical organization structure as FVIII. The domains FV and FVIII are significantly homologous and have approximately $40 \%$ of identical sequences.

FV maturation involves extensive post-ribosomal modulation. Recently studies have been focusing particularly on N-glycosylation. 37 glycosylation sites and their effect on the structure and function of co-factors have been studied. Divergent glycosylation of the $\mathrm{C} 2$ domain leads to the creation of two different variations of $\mathrm{FV}$ termed $\mathrm{FV}_{1}$ and $\mathrm{FV}_{2}$. Both variations circulate in the plasma in a ratio of 33:67 ( $\left.\mathrm{FV}_{1} / \mathrm{FV}_{2}\right)$. These two variants possess different properties (pro- and anticoagulatory) and in model cases also act differently ${ }^{51}$.

\section{Procoagulation function of FVa}

Inactivated $\mathrm{FV}$ has a low procoagulation activity until activated by a small amount of thrombin or FXa by cleavage in the sites Arg709, Arg 1018 and Arg 1545. This FVa molecule created by activation is a heterodimer ${ }^{52}$.

Unlike FV, FVa increases the FXa activated conversion of prothrombin in the prothrombinase complex. It may be expected that the cleaved B-domain allosterically inhibits the binding of $\mathrm{FV}$ in the active site of $\mathrm{FXa}\left(\right.$ ref.$\left.^{53}\right)$.

The mechanism by which FVa acts on FXa is not completely understood. Based on the latest works, it may be assumed that FVa increases the binding affinity of FXa to phospholipids by about 100x. In addition, it was determined that FVa in the prothrombinase complex does not change the binding site of FXa, but instead increases the affinity of the prothrombinase complex to prothrombin and ensures an increase in binding sites.

The co-factor activity of FVa is balanced by APC, which proteolytically cleaves FVa at the Arg306, Arg506 and Arg679 sites of the heavy chain. The weakest inactivation is seen during cleavage at the Arg679 site. Latest discoveries suggest two pathophysiological models of FVa cleavage. The first model assumes preferential cleavage at the $\operatorname{Arg} 506$ site followed by cleavage at the $\operatorname{Arg} 306$ site. Alternatively, FVa may be inactivated directly by cleavage at the $\operatorname{Arg} 306$ site. Cleavage at the $\operatorname{Arg} 506$ site also decreases the affinity of FVa to FXa, while cleavage at the Arg306 site causes complete inactivation of FVa $\left(\right.$ ref. $\left.{ }^{54}\right)$.

\section{Anticoagulation function of FVa}

Aside from its procoagulation function, FVa also possesses an anticoagulation function, which is expressed in the case of APC activation. In this case it stimulates proteolytic cleavage of FVIIIa (ref. ${ }^{55}$ ). Recent experimental works supports this model where the addition of purified FV renewed the function of APC in both healthy patients and in families with the Leiden mutation. The experiments utilized measured generation of thrombin.

Thus if the anticoagulation function of $\mathrm{FV}$ is required, cleavage must occur in position Arg506. Unlike APC mediated cleavage in sites Arg306 and Arg679, which does not exhibit anticoagulation activity. 


\section{FV and thrombophilia}

Such described pathways of FV activation point to the balance of pro- and anticoagulation activity of factor $\mathrm{V}$ and its significance in maintaining haemostatic equilibrium.

\section{The effect of FV Leiden mutation on the procoagulation and anticoagulation forms of $\mathrm{FV}$}

APC resistance is an in vitro described phenomenon, which is characterized by a slight anticoagulation response to APC in plasma. Such decreased sensitivity to APC leads to inadequate regulation of thrombin production. As such, APC resistance is associated with an increased risk of developing thrombosis. APC resistance is associated with FV Leiden mutation in up to $90 \%$ of cases.

FV Leiden mutation significantly influences the proand anticoagulation balance of FVa. The Leiden mutation, which leads to the disappearance of the Arg506 cleavage site, causes an insufficient decrease of the procoagulation activity of FVa, which explains the procoagulation states in carriers of the Leiden mutation ${ }^{56}$. However, recent publications have shown that PS and FXa may completely eliminate the effects of APC caused by the inactivation of FVa and FVIIIa. This may sufficiently explain the effect of low molecular weight heparins in the prevention of thromboembolic disease in carriers of FV Leiden mutations.

The discovery of a second pathway of action of FVa, where via APC it acts as a co-factor during proteolytic cleavage of FVIIIa aids us in establishing the effect of the Leiden mutation. Since FV with the Leiden mutation does not contain a cleavage site in the position Arg506, the anticoagulation form $\mathrm{FV}_{\mathrm{ac}}$ cannot be produced and therefore there is only weak co-factor activity of APC during FVIII proteolysis.

\section{DISCUSSION}

Genetic defects alone may not explain the pathological effect of APC resistance in certain cases. Recently, the incidence of inhibitors against FV has been described, which may also increase the expression of APC resistance. Inhibitors against FV may develop even from small quantities of bovine thrombin, which is added to fibrinogen derivatives obtained from cryoprecipitate ${ }^{57}$.

The elucidation of the precise pathogenesis of action of FV Leiden leads to the conclusion that to explain the clinical expression of thrombophilic conditions, it is most important to understand the interaction of at least one genetically dependent thrombophilia with one or more acquired conditions.

\section{ACKNOWLEDGEMENT}

This work was supported by the Grant IGA MZ NR9282/2007.

\section{REFERENCES}

1. Reitsma PH, Rosendaal FR. Past and future of genetic research in thrombosis. J Thromb Haemost. 2007, Jul 5; Suppl 1:264-9.

2. Rees DC, Cox M, Clegg JB. World distribution of factor V Leiden. Lancet. 346, 1995, 1133-1134.

3. Rosendaal FR, Koster T, Vandenbroucke JP, Reitsma PH. High risk of thrombosis in patients homozygous for factor $\mathrm{V}$ Leiden (activated protein C resistance). Blood. 85, 1995, 1504-1508.

4. Ridker PM, Miletich JP, Hennekens CH, Buring JE. Ethnic distribution of factor V Leiden in 4047 men and women. JAMA. 277, 1997, 1305-1307.

5. Vorlova Z., Hrachovinova I., Matyskova M. Probability of thrombosis in patients with factor V Leiden. Thromb.Haemost. 78:1, 1997, 309.

6. Chrobák, L., Dulíček, P.: Resistance to activated protein C as pathogenic factor of venous thromboembolism. - Acta Medica (Hradec Králové). - 39,(2), 1996, 55-62.

7. Dulíček P., Šafářová M., Chrobák L. Mutace FV Leiden nejčastější rizikový faktor pro vznik žiln í trombózy. Hematológia a transfuziológia. 4, 1997, 6-9.

8. Bertina RM, Koeleman RPC, Koster T, Rosendaal FR, Dirven RJ, De Ronde H, Van der Velden PA, Reitsma PH. Mutation in blood coagulation factor $\mathrm{V}$ associated with resistance to activated protein C. Nature. 369, 1994, 64-67.

9. Dahlbäck B, Carlsson M, Svensson PJ. Familial thrombophilia due to a previously unrecognised mechanism characterized by poor anticoagulant response to activated protein $\mathrm{C}$ : prediction of a cofactor to activated protein C. Proc Natl Acad Sci USA. 90, 1993, 1004-1008.

10. Koster T, Rosendaal FR, De Ronde H, Briët E, Vandenbroucke JP, Bertina RM. Venous thrombosis due to a poor anticoagulant response to activated protein C: Leiden Thrombophilia Study. Lancet. 342, 1993, 1503-1506.

11. Ridker PM, Hennekens CH, Lindpainter K, Stampfer MJ, Eisenberg PR, Miletich JP. Mutation in the gene coding for coagulation factor $\mathrm{V}$ and the risk of myocardial infarction, stroke, and venous thrombosis in apparently healthy men. $\mathrm{N}$ Engl J Med. 332, 1995, 912-917.

12. Anderson FA, Wheeler HB, Goldberg RJ, Hosmer DW, Patwardhan NA, Jovanovic B, Forrier A, Dalen JE. A population based perspective of the hospital incidence and case-fatality rates of deep vein thrombosis and pulmonary embolism. The Worcester DVT study. Arch Intern Med. 151, 1991, 933-938.

13. Poort SR, Rosendaal FR, Reitsma PH, Bertina RM. A commongenetic variation in the 3'-untranslated region of the prothrombin gene is associated with elevated plasma prothrombin levels and an increase in venous thrombosis. Blood. 88, 1996, 3698-3703.

14. Rosendaal FR, Doggen CJM, Zivelin A, Arruda VR, Aiach M, Siscovick DS, Hillarp A, Watzke HH, Bernardi F, Cumming AM, Preston FE, Reitsma PH. Geographic distribution of the 20210 G to A prothrombin variant. Thromb Haemost. 79, 1998, 706-708.

15. Matýšková M., Buliková A., Šlechtová M., Janků L. The prevalence of the prothrombin mutation 20210A in Brno, XV meeting of the ISH - African and European division, Final programme and abstracts, 124 .

16. Souto JC, Coll I, Llobet D, del Río E, Oliver A, Mateo J, Borrell M, Fontcuberta J. The prothrombin 20210A allele is the most present genetic risk factor for venous thromboembolism in the Spanish population. Thromb Haemost. 80, 1998, 366-369.

17. Falcon CR, Cattaneo M, Panzeri D, Martinelli I, Mannucci PM. High prevalence of hyperhomocyst(e)inemia in patients with juvenile venous thrombosis. Arterioscler Thromb. 14, 1994, 1080-1083.

18. Den Heijer M, Koster T, Blom HJ, Bos GMJ, Briët E, Reitsma PH, Vandenbroucke JP, Rosendaal FR. Hyperhomocysteinemia as a risk factor for deep-vein thrombosis. N Engl J Med. 334, 1996, 759-762.

19. Simioni P, Prandoni P, Burlina A, Tormene D, Sardella C, Ferrari V, Benedetti L, Girolami A. Hyperhomocysteinemia and deep-vein thrombosis: a case-control study. Thromb Haemost. 76, 1996, 883886.

20. Hyánek J., Hoffman R. Hyperhomocysteinémie a její diagnostický význam u cévních onemocnění. Praktická flebologie. 2, 1997, 61-71. 
21. D'Angelo A, Selhub J. Homocysteine and thrombotic disease. Blood. 90, 1997, 1-11.

22. Kang SS, Wong PWK, Norusis M. Homocysteinemia due to folate deficiency. Metabolism. 36, 1987, 458-462.

23. Kang SS, Wong PWK, Norusis M. Homocysteinemia due to folate deficiency. Metabolism. 36, 1987, 458-462.

24. Rees MM, Rodgers GM. Homocysteinemia: association of a metabolic disorder with vascular disease and thrombosis. Thrombosis Research. 71, 1993, 337-359.

25. Ubbink JB, Vermaak WJ, Van der Merwe A, Becker PJ. Vitamin B12, vitamin B6, and folate nutritional status in men with hyperhomocysteinemia. Am J Clin Nutr. 57, 1993, 47-53.

26. Mudd SH, Skovby F, Levy HL, Pettigrew KD, Wilcken B, Pyeritz RE, Andria G, Boers GH, Bromberg IL, Cerone R. The natural history of homocystinuria due to cystathionine beta-synthase deficiency. Am J Hum Genet. 37, 1985, 1-31.

27. Engbertsen AMT, Franken DG, Boers GHJ, Stevens EMB, Grijbels FJM, Blom HJ. Thermolabile 5,10-methylenetetrahydrofolate reductase as a cause of mild hyperhomocysteinemia. Am J Hum Genet. 56, 1995, 142-150.

28. Frosst P, Blom HJ, Milos R, Goyette P, Sheppard CA, Matthews RG, Boers GHJ, Den Heijer M, Kluijtmans LAJ, Van den Heuvel LPWJ, Rozen R. A candidate genetic risk factor for vascular disease: a common mutation in methylenetetrahydrofolate reductase. Nat Genet. 10, 1995, 111-113.

29. Egeberg O. Inherited antithrombin deficiency causing thrombophilia. Thromb Diath Haemorrh. 13, 1965, 516-530.

30. Thaler E, Lechner K. Antithrombin III deficiency and thromboembolism. Clin Haematol. 10, 1981, 369-390.

31. Demers C, Ginsberg JS, Hirsh J, Henderson P, Blajchman MA. Thrombosis in antithrombin III deficient persons: report of a large kindred and literature review. Ann Intern Med. 116, 1992, 754-761.

32. Hirsh J, Piovella F, Pini M. Congenital antithrombin III deficiency: incidence and clinical features. Am J Med. 87, 1989, 34-38.

33. Lane DA, Mannucci PM, Bauer KA, Bertina RM, Bochkov NP, Boulyjenkov V, Chandy M, Dahlbäck B, Ginter EK, Miletich JP, Rosendaal FR, Seligsohn U. Inherited Thrombophilia: Part 1. Thromb Haemost. 76, 1996, 651-662.

34. Tait RC, Walker ID, Perry DJ, Islam SI, Daly ME, McCall F, Conkie JA, Carrell RW. Prevalence of antithrombin deficiency in the healthy population. Br J Haematol. 87, 1994, 106-112.

35. Bock, S.C. et al.: Assignement of the huan antithrombin III structual gene to chromosome 1q23-25. Cytogenet. Cell Genet., 39, $1985,67-69$

36. Lane D.A. et al.: Antithrombin III: A database of mutations. Thrombos. Haemostasis, 66, 1991, 657-661.

37. Griffin JH, Evatt B, Zimmerman TS, Kleiss AJ, Wideman C. Deficiency of protein $\mathrm{C}$ in congenital thrombotic disease. J Clin Invest. 68, 1981, 1370-1373.

38. Allaart CF, Poort SR, Rosendaal FR, Reitsma PH, Bertina RM, Briët E. Increased risk of venous thrombosis in carriers of protein C deficiency defect. Lancet. 341, 1993, 134-138.

39. Broekmans AW, Veltkamp JJ, Bertina RM. Congenital protein C deficiency and venous thromboembolism: a study of three Dutchfamilies. N Engl J Med. 309, 1983, 340-344.

40. Allaart CF, Poort SR, Rosendaal FR, Reitsma PH, Bertina RM, Briët E. Increased risk of venous thrombosis in carriers of protein C deficiency defect. Lancet. 341, 1993, 134-138.

41. Koeleman BPC, Reitsma PH, Allaart CF, Bertina RM. APCresistance as an additional risk factor for thrombosis in protein $\mathrm{C}$ deficient families. Blood. 84, 1994, 1031-1035.
42. Heijboer H, Brandjes DPM, Büller HR, Sturk A, Ten Cate JW. Deficiencies of coagulation-inhibiting and fibrinolytic proteins in outpatients with deep-vein thrombosis. N Engl J Med. 323, 90,15121516.

43. Mateo J, Oliver A, Borrell M, Sala N, Fontcuberta J, the EMET Group. Laboratory evaluation and clinical characteristics of 2,132 consecutive unselected patients with venous thromboembolismresults of the Spanish multicentric study on thrombophilia(EMETstudy). Thromb Haemost. 77, 997,444-451.

44. Koster T, Rosendaal FR, Briët E, Van der Meer FJM, Colly LP, Trienekens PH, Poort SR, Vandenbroucke JP. Protein C deficiency in a controlled series of unselected outpatients: an infrequent but clear risk factor for venous thrombosis (Leiden hrombophilia Study). Blood. 85, 1995, 2756-2761.

45. Reitsma PH, Bernardi F, Doig RG, Gandrille S, Greengard JS, Ireland H, Krawczak M, Lind B, Long GL, Poort SR, Saito H, Sala N, Witt I, Cooper DN. Protein C deficiency a database of mutations. 1995 Update. Thromb Haemost. 73, 1995, 876-889.

46. Walker I.D. et al. Guidelines on the Investigation ona Management of Thrombophilia. J. Clin Path, 43, 1990, 703-709.

47. Cripe LD, Moore KD, Kane WH. Structure of the gene for human coagulation factor V. Biochemistry 1992; 31:3777-3785.

48. Jenny RJ, Pittman DD, Toole JJ, et al. Komplete cDNA and derived amino acid sequence of human factor V. Proc Natl Acad Sci USA 1987; 84:4846-4850.

49. Tracy PB, Eide LL, Bowie EJ, et al. Radioimmunoassay of factor $\mathrm{V}$ in human plasma and platelets. Blood 1982; 60:59-63.

50. Suehiro Y, Veljkovic DK, Fuller N, et al. Endocytosis and storage of plasma factor $\mathrm{V}$ by human megakaryocytes. Thromb Haemost 2005; 94:585-592.

51. Hoekema L, Nicolaes GAF, Hemker HC, et al. Human factor Va 1 and factor Va2: properties in the procoagulant and anticoagulant pathways. Biochemistry 1997; 36:3331-3335.

52. Esmon CT. The subunit structure of thrombin-activated factor V. Isolation of activated factor $\mathrm{V}$, separation of subunits, and reconstitution of biological activity. J Biol Chem 1979; 254:964-973.

53. Husten EJ, Esmon CT, Johnson AE. The active site of blood coagulation factor $\mathrm{Xa}$. Its distance from the phospholipid surface and its conformational sensitivity to components of the prothrombinase complex. J Biol Chem 1987; 262:12953-12961.

54. Yegneswaran S, Fernandez JA, Griffin JH, et al. Factor Va increases the affinity of factor Xa for prothrombin: a binding study using a novel photoactivable thiol-specific fluorescent probe. Chem Biol 2002; 9: 485-494.

55. Dahlbäck B, Carlsson M, Svensson PJ. Familial thrombophilia due to a previously unrecognized mechanism characterized by poor anticoagulant response to activated protein C: prediction of a cofactor to activated protein C. Proc Natl Acad Sci USA 1993; 90:1004-1008.

56. Bertina RM, Koeleman BP, Koster T, et al. Mutation in blood coagulation factor $\mathrm{V}$ associated with resistence to activated protein C. Nature 1994; 369:64-67.

57. Leroy-Matheron C, Mallat A, Duvoux C, et al. Inhibitor against coagulation factor $\mathrm{V}$ after liver transplantation. Transplantation 1999; 68: 1054-1056.

58. Reitsma PH, Rosendaal FR. Past and future of genetic research in thrombosis. J Thromb Haemost. 2007 Jul;5 Suppl 1:264-9

59. Segers K., Dahlbäck B, Nicolaes G. Coagulation factor V and thrombophilia: Background and mechanisms. Thromb Haemost 2007; 98: 530-542 
